\title{
Normal Values of T, B and NK Lymphocyte Subpopulations in Peripheral Blood of Healthy Cuban Adults
}

\author{
Elena Kokuina MD PhD, Martha C. Breff-Fonseca MD, Carlos A. Villegas-Valverde MD MS, Isabel Mora-Díaz MD
}

\begin{abstract}
INTRODUCTION Quantification of lymphocyte subpopulations is useful for evaluating immune response in states of health and disease, including immunodeficiencies, autoimmunity, infections and cancer. Studies have found that concentrations and proportions of different cell subpopulations vary with geographic location, age, sex and ethnicity. Knowing the normal values of these cells and their variation in healthy populations will contribute to improved clinical practice and scientific research.
\end{abstract}

OBJECTIVE Estimate normal absolute concentrations and percentages of the most abundant lymphocyte subpopulations in peripheral blood and their relation to sex and age.

METHODS A cross-sectional analysis was conducted in 129 healthy adults, 61 men and 68 women aged $18-80$ years; 89 aged $<50$ years and $40 \geq 50$ years. We included individuals who agreed to participate by written informed consent. Exclusion criteria were chronic disease, or use of tobacco, alcohol or medications that can alter immune system cell numbers and functions.

Through dual platform flow cytometry, we determined absolute and percentage values for $T$ lymphocyte subsets $C D 3+, C D 3+/ C D 4+T$, CD3+/CD8+T, CD19+ B cells and CD3-/CD56+ natural killer cells in peripheral blood, using an 8-color flow cytometer. We estimated medians and the 2.5 and 97.5 percentiles and calculated the Pear-

\section{INTRODUCTION}

Quantification of lymphocyte subpopulations by flow cytometry is considered the most exact and reliable procedure to assess immunocompetence, which allows the body to maintain homeostasis against invading pathogens and the body's own damaged cells that would otherwise have adverse health effects. Numerous diseases are associated with alterations in peripheral blood lymphocyte subpopulations, including primary or congenital immunodeficiencies, in which certain lymphocyte subpopulations are absent or reduced; secondary immunodeficiencies including HIV infection, which destroys the CD4+ T cell subpopulation; systemic autoimmune diseases; infections; and cancer. Quantification of lymphocyte subpopulations is necessary in these clinical conditions to establish diagnosis, and as a criterion of disease progression and treatment optimization.[1-3]

Normal or reference values of lymphocyte subpopulations obtained in several countries show association with ethnicity,

IMPORTANCE This study takes a first step toward establishing normal values of the most abundant lymphocyte subpopulations in peripheral blood of healthy Cuban adults using flow cytometry as a basis for more accurate clinical diagnosis of immune disorders in Cuba. son correlation coefficient to evaluate associations. Significance tests were also used to compare groups. The significance threshold was $p=0.05$ in all cases.

RESULTS Ranges of absolute values and percentages (\%) were: total lymphocytes: 1200-3475 cells/ $\mu \mathrm{L}$ (20.2-49.3); CD3+ T cells: 880-2623

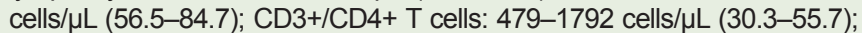
CD3+/CD8+ T cells: 248-1101 cells/ $\mu \mathrm{L}$ (13.2-42.9); CD19+ B cells: 1141491 cells/ $\mu \mathrm{L}$ (5.4-49.5); CD3-/CD56+ natural killer cells: 70-652 cells/ $\mathrm{LL}$ (3.7-28.0); and the CD4+:CD8+ index: 0.80-3.92. Absolute numbersbut not percentages - of lymphocytes and $\mathrm{CD} 3+\mathrm{T}$ cells were higher in those $<50$ years $(p=0.025$ and 0.020 , respectively). Absolute values and relative percentages of $C D 3+/ C D 8+$ and relative values of $C D 3+/ C D 4+$ T cells were significantly higher in the younger subgroup $(p=0.004$ and $p=0.047$ ). Age was not associated significantly with $B$ lymphocytes or natural killer cells. Absolute and relative values of CD3+/CD4+ T lymphocytes were significantly higher in women ( $p=0.009$ and 0.036 , respectively).

CONCLUSIONS. Absolute numbers of total lymphocytes and $T$ and CD3+/CD8+ T lymphocytes are higher in younger individuals. In percentage values, CD3+/CD4+ $T$ lymphocytes are lower in older persons. Absolute and percentage values of $C D 3+/ C D 4+T$ phenotype are higher in women. These differences justify adjusting clinical analyses to different values by age and sex.

KEYWORDS T lymphocytes, B lymphocytes, normal values, flow cytometry, age, sex, Cuba

sociodemographic factors (including age and sex) and environmental factors such as exposure to infectious agents.[4-6 ] Interpretation of lymphocyte subpopulation data for clinical practice requires establishing normal ranges for local populations. These ranges have not been defined for the Cuban population.

The study objective was to estimate absolute and relative values of peripheral lymphocyte subpopulations of CD3+, CD3+/CD4+, CD3+/CD8+ T cells, CD19+ B cells, CD3-/56+ natural killer cells, the CD4+:CD8+ index and the variation in their distribution by age and sex in healthy Cuban adults.

\section{METHODS}

Design, subjects and sample A cross-sectional study was conducted from January through April 2017 in 129 healthy adults, 61 men and 68 women, aged 18-80 years, of whom 89 were $<50$ and 40 were $\geq 50$ years. Average age was 43.5 for men and 37.8 for women. The proportion of men and women was similar in both age groups $(p=0.172)$. Participants were hospital workers and patient companions recruited in the clinical laboratory of the Hermanos Ameijeiras Clinical-Surgical Teaching Hospital in Havana (HCQHA), Cuba. After agreeing to participate on the basis of written informed consent, they completed a questionnaire requesting information on demographic characteristics (age, sex, and schooling), lifestyle, medication consumption and personal medical history. Subjects with the following characteristics were excluded: present tobacco or al- 
cohol use, treatment with immunosuppressive and immunomodulatory drugs in the previous six months, pregnant women, and those with acute or chronic infectious diseases such as HIV, hepatitis B, hepatitis C and tuberculosis; chronic metabolic diseases; and cardiac, pulmonary, renal, cerebral, systemic, allergic and neoplastic autoimmune diseases.

Peripheral blood samples were obtained by antecubital venous puncture, collected in vacutainer tubes containing ethylenediaminetetraacetic acid (EDTA) as anticoagulant, and processed by flow cytometry within four hours following best laboratory practices. Absolute and differential blood cell count was calculated for all samples using an automated hematology analyzer (Horiba Medical, France).

Flow cytometry Lymphocyte subpopulations were determined in whole peripheral blood, lysed using a Versalyse buffer (Beckman Coulter, France) without washing. For immunophenotyping using fluorochrome conjugated monoclonal antibodies anti-CD45 AA750 (Clone J33), antiCD19-PC7 (Clone J3-119), anti-CD3 FITC (Clone UCHT1), anti-CD4 PC5.5 (Clone 13B8.2), antiCD8 AA700 (Clone B9.11) and anti-CD56 PE (Clone N901) (NKH-1), $100 \mu \mathrm{L}$ of blood were dispensed. Sample preparation was carried out according to manufacturer guidelines.

Lymphocyte subpopulations were characterized by combining monoclonal antibodies for $\mathrm{T}, \mathrm{B}$ and NK cells:

T cells: (CD45+, CD3+); (CD45+, CD3+, CD4+); (CD45+, CD3+, CD8+)

B cells: (CD45+, CD19+)

NK cells: (CD45+, CD56+, CD3-).

Sample collection was carried out with an 8-color Gallios flow cytometer (Beckman Coulter, France), using Kaluza Acquisition software for Gallios, Version 1.0 (Beckman Coulter, France). For each sample, a minimum of 10,000 events were collected (referring to number of cells in the sample of lysed red blood cells passing the cytometer's laser beam for counting and analysis).

In each case, more than 4,000 events were obtained in the lymphocyte gate, characterized by high expression of CD45 and low side-scatter complexity (SSC). Figure 1 shows the gate strategy with a dot plot, which starts by eliminating doublets (cells passing the interrogation point in groups), followed by a plot removing artifacts and detritus (forward scatter vs. side scatter) and from which the lymphocyte population was selected. Plots were generated from this lymphocyte region by combining two of the antigens expressed on the cell surface with separation by quadrants, allowing identification and determination of percentage of subpopulations.

Data were analyzed with Kaluza Analysis software V 1.2 (Beckman Coulter, France). Absolute counts of lymphocyte subpopula- tions were calculated by dual platform, from percentages obtained by flow cytometry and lymphocyte counts obtained by hematological analyzer (Horiba Medical, Montpellier, France) using the formula:

Absolute count (cells $/ \mu \mathrm{L})=$ Lymphocyte count (cell number $/ \mu \mathrm{L}$ of the blood count) $x$ proportion of the cell subpopulation of interest $\div 100$.

Internal quality control was performed daily by checking the cytometer's optical detector and aligning lasers and fluid systems using Flow-SET Fluorospheres and Flow-Check Fluorospheres (Beckman Coulter, France), respectively, according to manufacturer guidelines.

Statistical analysis Descriptive statistics were calculated for absolute and relative frequencies, means, medians, standard deviations (SD) and reference ranges of percentage and absolute values for each cell marker. The Kolmogorov-Smirnov test was used to test the normal distribution of variables. Ref- 
erence ranges were defined as 2.5-97.5 percentiles. The Student $t$ test was applied for variables with Gaussian distribution and the two-tailed Mann Whitney $U$ test for independent samples to evaluate the influence of sex and age on peripheral lymphocyte concentrations. Age association with cell values was calculated using the Pearson correlation coefficient. The significance threshold was $p=0.05$. Statistical analysis was done with SPSS v 20.0 software for Windows XP.

Ethics The project was approved by the HCGHA research ethics committee. All participants were asked if they were willing to participate and joined the study only after providing written informed consent, in compliance with the Helsinki Declaration.[7] The consent form explained the importance of participating, characteristics of the research, and possible risks and benefits. Data storage adhered to principles of confidentiality and data were deidentified. The selection of diagnostic means followed principles of maximum benefit, the ethics rule of do no harm, and best laboratory practices.

\section{RESULTS}

Means, standard deviations, medians and reference ranges of absolute values and percentages of lymphocyte subpopulations are shown in Table 1. Absolute values are expressed in number of cells per microliter and percentages refer to relative frequencies of each subpopulation in relation to total lymphocytes.

Table 2 shows ranges of lymphocyte subpopulations in absolute numbers, age ranges and sex composition obtained for Cuban adults in this study and in studies conducted in five countries, where differences can be observed in cell concentrations as well as technologies and platforms used.

Table 1: Ranges for peripheral blood lymphocyte subpopulation values in healthy Cuban adults $(\mathrm{N}=129)$

\begin{tabular}{|c|c|c|c|}
\hline Parameter & $\begin{array}{l}\text { Mean } \\
\text { (SD) }\end{array}$ & Median & $\begin{array}{c}\text { Percentile } \\
\text { range } \\
2.5-97.5\end{array}$ \\
\hline $\begin{array}{l}\text { Lymphocytes (cells } / \mu \mathrm{L} \text { ) } \\
\%\end{array}$ & $\begin{array}{r}2177(573) \\
33.8(7.5)\end{array}$ & $\begin{array}{r}2200 \\
32.3\end{array}$ & $\begin{array}{r}1200-3475 \\
20.2-49.3\end{array}$ \\
\hline $\begin{array}{l}\text { CD3+ T cells (cells/ } \mu \mathrm{L}) \\
\%\end{array}$ & $\begin{array}{r}1579(446) \\
72.6(7.3)\end{array}$ & $\begin{array}{r}1508 \\
73.0\end{array}$ & $\begin{array}{l}880-2623 \\
56.5-84.7\end{array}$ \\
\hline $\begin{array}{l}\text { CD3+/CD4+ T cells (cells/ } \mu \mathrm{L}) \\
\%\end{array}$ & $\begin{array}{l}945(292) \\
43.6(7.0)\end{array}$ & $\begin{array}{r}904 \\
43.8\end{array}$ & $\begin{array}{l}479-1792 \\
30.3-55.7\end{array}$ \\
\hline $\begin{array}{l}\text { CD3+/CD8+T cells (cells/ } \mu \mathrm{L}) \\
\%\end{array}$ & $\begin{array}{l}583(232) \\
26.7(7.3)\end{array}$ & $\begin{array}{r}540 \\
26.0\end{array}$ & $\begin{array}{l}248-1101 \\
13.2-42.9\end{array}$ \\
\hline $\begin{array}{l}\text { CD19+ B cells (cells } / \mu L) \\
\%\end{array}$ & $\begin{array}{r}559(368) \\
25.0(12.8)\end{array}$ & $\begin{array}{r}452 \\
25.6\end{array}$ & $\begin{array}{r}114-1491 \\
5.4-49.5\end{array}$ \\
\hline 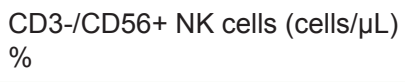 & $\begin{array}{l}297(166) \\
13.7(6.5)\end{array}$ & $\begin{array}{r}256 \\
12.7\end{array}$ & $\begin{array}{r}70-652 \\
3.7-28.0\end{array}$ \\
\hline CD4+:CD8+ index & $1.81(0.73)$ & 1.73 & $0.80-3.92$ \\
\hline
\end{tabular}

SD: standard deviation
Table 2: Lymphocyte subpopulation values (percentile $2.5-97.5$, cells $/ \mu \mathrm{L}$ ) in selected populations of healthy adults, by country

\begin{tabular}{|c|c|c|c|c|c|c|}
\hline & $\begin{array}{l}\text { Cuba } \\
\text { (this } \\
\text { study) }\end{array}$ & $\begin{array}{l}\text { Brazil } \\
(8)\end{array}$ & $\begin{array}{l}\text { Peru } \\
(9)\end{array}$ & $\begin{array}{l}\text { Korea } \\
\text { (11) }\end{array}$ & $\begin{array}{l}\text { Germany } \\
\text { (4) }\end{array}$ & $\begin{array}{c}\text { Tanzania } \\
(10)\end{array}$ \\
\hline n & 129 & 641 & 318 & 294 & 100 & 274 \\
\hline $\begin{array}{l}\text { Men/women } \\
\text { (n) }\end{array}$ & $61 / 68$ & $404 / 237$ & $197 / 121$ & $139 / 155$ & $50 / 50$ & $143 / 131$ \\
\hline $\begin{array}{l}\text { Age } \\
\text { (years: mean) }\end{array}$ & 41 & 33 & 30 & 47 & $43^{a}$ & $29 ; 26^{\mathrm{b}}$ \\
\hline $\begin{array}{l}\text { Age range } \\
\text { (years) }\end{array}$ & $18-80$ & $19-56^{c}$ & $18-55$ & $21-80$ & $19-85$ & $19-48$ \\
\hline $\begin{array}{l}\text { Technology/ } \\
\text { platform }\end{array}$ & $\begin{array}{r}\text { Gallios/ } \\
\text { dual }\end{array}$ & $\begin{array}{r}\text { FACS } \\
\text { Calibur/ } \\
\text { single }\end{array}$ & $\begin{array}{r}\text { Cytomics/ } \\
\text { single }\end{array}$ & $\begin{array}{r}\text { FACS } \\
\text { Calibur/ } \\
\text { single }\end{array}$ & $\begin{array}{r}\text { FACS } \\
\text { Calibur/ } \\
\text { dual }\end{array}$ & $\begin{array}{r}\text { FACS } \\
\text { Calibur/ } \\
\text { dual }\end{array}$ \\
\hline Lymphocytes & $1200-3475$ & $1257-4104$ & na & $1178-3262$ & $1140-3380$ & $1168-3320$ \\
\hline $\begin{array}{l}\text { CD3+ } \\
\text { T cells }\end{array}$ & $880-2623$ & 1025-2904 & 818-2838 & 708-2294 & $780-2240$ & 683-2106 \\
\hline $\begin{array}{l}\text { CD3+/CD4+ } \\
\text { T cells }\end{array}$ & $479-1792$ & 540-1731 & $436-1510$ & 394-1574 & $490-1640$ & 406-1392 \\
\hline $\begin{array}{l}\text { CD3+/CD8+ } \\
\text { T cells }\end{array}$ & 248-1101 & 263-1189 & 236-982 & 188-830 & $170-880$ & 188-990 \\
\hline $\begin{array}{l}\text { CD19+ } \\
\text { B cells }\end{array}$ & $114-1491$ & na & $151-730$ & $57-461$ & $80-490$ & $109-637$ \\
\hline NK cells & $70-652$ & na & 139-789 & $91-682$ & $80-690$ & $123-801$ \\
\hline $\begin{array}{l}\text { CD4+:CD8+ } \\
\text { index range }\end{array}$ & $0.80-3.92$ & na & $0.84-3.06$ & $0.77-4.42$ & $0.9-5.0$ & $0.83-3.19$ \\
\hline
\end{tabular}

a: median; b: median of men and women respectively; c: Interquartile range; na: not available

Percentages and absolute values of cell subpopulations were related to age. Regression analysis showed that absolute lymphocyte counts $(r=-0.265 ; p=0.002)$, CD3 $+T$ cells $(r=-0.314$; $p=0.0001)$ and $C D 3+/ C D 8+(r=-0.326 ; p=0.0001)$ significantly decrease with age; while the CD4+:CD8+ index significantly increases $(r=0.263, p=0.003)$

The total number of lymphocytes and other cells in the T cell compartment were associated with age, with lower absolute values of $C D 3+T$ and $C D 3+/ C D 8+T$ cells in the older age group. The $\mathrm{CD} 3+/ \mathrm{CD} 4+\mathrm{T}$ cell fraction had higher concentrations in participants aged $\geq 50$ years. CD19+ B lymphocyte and CD3-/CD56+ NK cell values did not change with age (Table 3 ).

Absolute numbers and percentages of $C D 3+/ C D 4+T$ cells were higher in women ( $p=0.009$ and $p=0.036$, respectively). The CD4+:CD8+ index had higher values in women $(p=0.043)$; there were no differences by sex for CD3-/CD19+ B lymphocytes and CD3-/CD56+ NK cells (Table 4).

\section{DISCUSSION}

This is the first study reporting normal absolute and percentage values for $T$ lymphocytes and their subpopulations, as well as $B$ lymphocytes and NK cells, in peripheral blood of healthy Cuban adults. Because clinical diagnoses based on measures drawn from local populations are more reliable, the study's results are a first step in the application of domestic data to diagnosis and clinical management of Cuban adults with diseases causing alterations of peripheral lymphocyte subpopulations.

Some authors have demonstrated the influence of ethnicity and certain sociodemographic characteristics on the composition of 
Table 3: Absolute values and percentages of lymphocyte subpopulations in healthy Cuban adults by age groups

\begin{tabular}{|c|c|c|c|c|c|}
\hline \multirow[t]{2}{*}{ Parameter } & \multicolumn{2}{|c|}{ Mean (SD) } & \multicolumn{2}{|c|}{$\begin{array}{c}\text { Percentile range } \\
2.5-97.5 \\
\end{array}$} & \multirow[b]{2}{*}{ p } \\
\hline & $<50$ years & $\geq 50$ years & $<50$ years & $\geq 50$ years & \\
\hline & $n=89$ & $n=40$ & $n=89$ & $n=40$ & \\
\hline $\begin{array}{l}\text { Lymphocytes (cells/ } \mu \mathrm{L}) \\
\%\end{array}$ & $\begin{array}{r}2257(531) \\
33.9(7.4)\end{array}$ & $\begin{array}{r}2000(626) \\
33.6(7.9)\end{array}$ & $\begin{array}{r}1300-3475 \\
20.2-51.0\end{array}$ & $\begin{array}{r}1200-3886 \\
18.0-49.6\end{array}$ & $\begin{array}{r}0.025 \\
\text { NS }\end{array}$ \\
\hline $\begin{array}{l}\text { CD3+ T cells }(\text { cells } / \mu \mathrm{L}) \\
\%\end{array}$ & $\begin{array}{r}1642(433) \\
72.7(7.5)\end{array}$ & $\begin{array}{r}1441(449) \\
72.5(6.9)\end{array}$ & $\begin{array}{l}859-2795 \\
56.5-85.0\end{array}$ & $\begin{array}{l}912-2625 \\
55.3-83.3\end{array}$ & $\begin{array}{r}0.020 \\
\text { NS }\end{array}$ \\
\hline $\begin{array}{l}\text { CD3+/CD4+ T cells (cells/ } \mu \mathrm{L}) \\
\%\end{array}$ & $\begin{array}{l}959(265) \\
42.7(6.7)\end{array}$ & $\begin{array}{l}913(346) \\
45.5(7.6)\end{array}$ & $\begin{array}{l}472-1766 \\
29.9-54.0\end{array}$ & $\begin{array}{l}475-2125 \\
31.0-65.9\end{array}$ & $\begin{array}{r}\text { NS } \\
0.047\end{array}$ \\
\hline $\begin{array}{l}\text { CD3+/CD8+ T cells (cells/ } \mu \mathrm{L}) \\
\%\end{array}$ & $\begin{array}{l}620(238) \\
27.1(7.2)\end{array}$ & $\begin{array}{l}501(198) \\
25.6(7.5)\end{array}$ & $\begin{array}{l}248-1110 \\
14.6-43.8\end{array}$ & $\begin{array}{r}224-960 \\
12.8-39.4\end{array}$ & $\begin{array}{r}0.004 \\
\text { NS }\end{array}$ \\
\hline $\begin{array}{l}\text { B CD19+ cells (cells } / \mu L) \\
\%\end{array}$ & $\begin{array}{r}578(377) \\
24.9(13.2)\end{array}$ & $\begin{array}{r}518(349) \\
25.3(12.2)\end{array}$ & $\begin{array}{r}126-1491 \\
5.4-50.0\end{array}$ & $\begin{array}{l}83-1640 \\
4.6-54.7\end{array}$ & $\begin{array}{l}\text { NS } \\
\text { NS }\end{array}$ \\
\hline 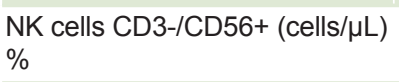 & $\begin{array}{l}305(169) \\
13.6(6.5)\end{array}$ & $\begin{array}{l}281(161) \\
14.0(6.7)\end{array}$ & $\begin{array}{r}67-652 \\
3.7-27.0\end{array}$ & $\begin{array}{r}76-760 \\
3.0-31.6\end{array}$ & $\begin{array}{l}\text { NS } \\
\text { NS }\end{array}$ \\
\hline CD4+:CD8+ index & $1.72(0.64)$ & $2.0(0.88)$ & $0.75-3.56$ & $0.79-4.70$ & NS \\
\hline
\end{tabular}

SD: standard deviation; NS: not significant

Table 4: Absolute values and percentages of lymphocyte subpopulations in healthy Cuban adults by sex

\begin{tabular}{|c|c|c|c|c|c|}
\hline & \multicolumn{2}{|c|}{ Mean (SD) } & \multicolumn{2}{|c|}{$\begin{array}{c}\text { Percentile range } \\
2.5-97.5\end{array}$} & \multirow[b]{2}{*}{$p$} \\
\hline & Men & Women & Men & Women & \\
\hline & $n=61$ & $n=68$ & $n=61$ & $n=68$ & \\
\hline 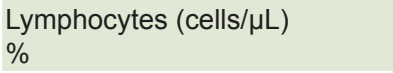 & $\begin{array}{r}2093(597) \\
32.6(7.5)\end{array}$ & $\begin{array}{r}2251(543) \\
34.9(7.5)\end{array}$ & $\begin{array}{r}1200-3445 \\
19.4-47.9\end{array}$ & $\begin{array}{r}1173-3755 \\
20.9-52.9\end{array}$ & $\begin{array}{l}\text { NS } \\
\text { NS }\end{array}$ \\
\hline $\begin{array}{l}\text { CD3+T cells }(\text { cells } / \mu \mathrm{L}) \\
\%\end{array}$ & $\begin{array}{r}1521(487) \\
72.5(7.8)\end{array}$ & $\begin{array}{r}1632(402) \\
72.7(6.8)\end{array}$ & $\begin{array}{l}863-2766 \\
55.2-85.9\end{array}$ & $\begin{array}{l}872-2695 \\
59.1-83.9\end{array}$ & $\begin{array}{l}\text { NS } \\
\text { NS }\end{array}$ \\
\hline 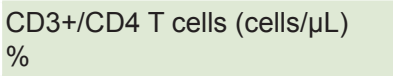 & $\begin{array}{l}875(263) \\
42.2(6.2)\end{array}$ & $\begin{array}{r}1007(304) \\
44.8(7.6)\end{array}$ & $\begin{array}{l}484-1683 \\
28.7-54.7\end{array}$ & $\begin{array}{l}446-1977 \\
30.0-61.9\end{array}$ & $\begin{array}{l}0.009 \\
0.036\end{array}$ \\
\hline $\begin{array}{l}\text { CD3+/CD8+T cells (cells } / \mu \mathrm{L}) \\
\%\end{array}$ & $\begin{array}{l}594(267) \\
27.8(7.6)\end{array}$ & $\begin{array}{l}574(197) \\
25.7(6.9)\end{array}$ & $\begin{array}{l}202-1194 \\
13.3-42.6\end{array}$ & $\begin{array}{l}259-1031 \\
12.4-44.3\end{array}$ & $\begin{array}{l}\text { NS } \\
\text { NS }\end{array}$ \\
\hline 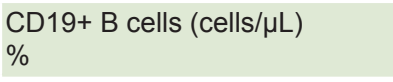 & $\begin{array}{r}570(409) \\
25.6(12.8)\end{array}$ & $\begin{array}{r}550(330) \\
24.5(13.0)\end{array}$ & $\begin{array}{l}84-1664 \\
5.4-55.5\end{array}$ & $\begin{array}{r}128-1229 \\
5.1-48.6\end{array}$ & $\begin{array}{l}\text { NS } \\
\text { NS }\end{array}$ \\
\hline $\begin{array}{l}\text { NK cells CD3/CD56+ (cells/ } \mu \mathrm{L}) \\
\%\end{array}$ & $\begin{array}{l}304(146) \\
14.9(6.6)\end{array}$ & $\begin{array}{l}291(184) \\
12.7(6.3)\end{array}$ & $\begin{array}{r}63-612 \\
3.1-29.8\end{array}$ & $\begin{array}{r}74-856 \\
3.4-28.3\end{array}$ & $\begin{array}{l}\text { NS } \\
\text { NS }\end{array}$ \\
\hline CD4+:CD8+ index & $1.67(0.61)$ & $1.93(0.81)$ & $0.76-3.39$ & $0.78-4.54$ & 0.043 \\
\hline
\end{tabular}

SD: standard deviation; NS: not significant

lymphocyte subpopulations. Regional differences have been reported within large countries such as Brazil, China and India. [1214] When we compare lymphocyte values between our study and those of other populations in America, Europe, Asia and Africa, differences between countries are observed which could be attributed not only to biological or sociodemographic factors such as age, sex and ethnicity, but also to environmental factors such as exposure to infectious agents, air pollution and lifestyles.[13-17] Taking into account the influence of environmental and sociodemographic factors and their changes over time, specific ranges of lymphocyte subpopulations should ideally be determined by geographically localized populations and updated through periodic re-evaluation.[11-18]

Average CD3+, CD3+/CD4+ and CD3+/CD8+ T lymphocyte subpopulations in our study are closer to those of other countries and areas of the American continent, such as south Florida (US),[17] Brazil,[8] and Peru,[9] than to those of Korea,[11] Germany, [4] Tanzania,[10] and China[14], which confirms the role of geographic, ethnic and lifestyle factors and exposure to infectious agents in modulating the values of peripheral lymphocytes and the immune system.[14,15,17,18] Determination of reference values for lymphocytic subpopulations by region and country makes for more reliable data interpretation in clinical cases.[8,12-14,18] The reliability of normal CD3+/CD4+ lymphocyte subpopulation values takes on special clinical importance in prognosis and treatment strategies for patients infected with HIV-1.[19]

Average absolute and percentage values of CD19+ $B$ cells in our study were higher than those reported in south Florida (US),[18] Korea,[11] Germany,[4] Tanzania,[10] and China.[14] One explanation for differences in lymphocyte subpopulation distribution is variations in infectious agent exposure, even within the same geographic region.[15,18] The greater expansion of peripheral B cells in our study participants could be associated with the presence of arboviral diseases, especially dengue virus, in this area. Dengue virus is endemic in most tropical and subtropical regions and the vast majority of infections are asymptomatic.[20] It has been reported that individuals exposed to dengue virus have abnormally high levels of activated B cells,[21] not only due to the clonal expansion of virus specific B cells, but also to virus-induced nonspecific polyclonal activation.[22]

Change in the number and composition of different lymphocyte subpopulations in peripheral blood is a distinctive characteristic of immune system aging. Numerous studies have shown the relationship between age and lymphocytic subpopulation concentrations. $[4,5,11,14,23,24]$ Several authors have reported lower levels of $\mathrm{CD} 3+$ and $\mathrm{CD} 3+1$ CD8+ $T$ lymphocytes in the elderly.[4,5,11,14, 24,25] Decreased effectiveness of senescent immune response reflects degeneration of lymphoid cell development and function at various levels. A lower potential of hematopoietic cells for lymphoid differentiation decreases the formation of immune cells.[26] T cellmediated immunity has been shown to be especially susceptible to aging due to decline in the number and diversity of naïve T cells affected by involution of the thymus, a primary lymphoid organ crucial for T lymphocyte generation and maturation.[27]

Reasons for decline of CD3+ and CD3+/CD8+ T cells in younger persons are still unknown; unlike CD3+/CD4+ T cells, whose values remained stable in older individuals in this study.[24] In each T cell subpopulation, naïve cell production decreases and memorycell accumulation increases with age. But the combinations of decreased naïve lymphocyte production and the accumulation of memory cells may be different within the CD3+/CD4+ and CD3+/ CD8+ subpopulations depending on total lymphocyte production and interactions with the environment over time.[28,29]

Depletion of a T cell compartment may occur at senescence in response to persistent infections. Stervbo found higher numbers of CD4+ $T$ cells specific for cytomegalovirus (CMV) in individuals 
aged 53-67 years, whereas presence of CMV-specific CD8+ T cells was not modified by age.[28] The differences in stability of the CD3+/CD4+ and CD3+/CD8+ T cells in relation to age could be attributed to these two subpopulations being regulated by different growth factors and cytokines.[30]

Previous studies reported a reduction in the CD4+:CD8+ index with increasing age, which constitutes the Immune Risk Profile associated with morbidity and mortality in old age.[31,32] Some investigations attribute the reduction in the CD4+:CD8+ index to immune response against CMV and have shown a negative association between the CD4+:CD8+ index and CMV seropositivity in old age.[33] Others observe no decrease in the CD4+:CD8+ index with respect to age, but do report a negative correlation between this ratio and CMV seropositivity.[29] In this study we did not find reduction of the CD4+:CD8+ index in older individuals, so the decline reported in the literature could be a characteristic of older adults infected with CMV.

Comparison of lymphocyte subpopulation levels between men and women found CD3+/CD4+ T cells were more numerous in women. Higher levels of this subpopulation in Cuban women in relation to men were more marked in absolute values than in the fraction of CD3+CD4+ T cells. Higher values of CD3+/CD4+ cells have been observed in women compared to men in different populations of Brazil,[8] Spain,[17] Korea, [11] France,[34] Israel,[23] and India.[6] Although no differences were found in lymphocyte subpopulations between men and women in a study of the south Florida (US) population, the CD4+:CD8+ index was higher in women.[18] For this to occur there should be more CD4+ cells or fewer CD8+ cells.

Absolute values of activated T cells within the CD3+ subpopulation (CD3+/HLA-DR/CD25) were also higher in Cuban women. [35] Unequal distribution of lymphocyte subpopulations between men and women and in particular the higher frequency of CD4+ T cells in women may explain their greater resistance to infectious diseases and greater likelihood of developing autoimmune diseases.[36,37] The difference in values of CD3+CD4+ cells can be attributed to the effect of sex hormones on their specific receptors expressed in T and B lymphocytes.[38]
Sex chromosome genes and sex hormones such as estrogen, progesterone and androgens contribute to male/female differences in immune response.[39] Estrogen is known to enhance both cell-mediated and humoral immune responses, while androgens suppress the differentiation of Th1 cells, and reduce gamma interferon (IFN- $\mathrm{Y}$ ) production and B-cell antibody responses.[40,41] In general, women develop stronger humoral and cellular responses than men, associated with higher levels of antibodies and other immune mediators such as IL-1, IL-4 and IFN-y.[42] Nutrition and microbiome composition also determine differences in development and functioning of immune response in men and women.[39]

We note several limitations of our study. The sample included only residents of Havana and none from other Cuban provinces. Additional serologic studies were not carried out, leaving open a possible sub-diagnosis of chronic and infectious diseases. Absolute values were calculated on a dual platform, which could be the source of inter-laboratory variability. However, no difference has been demonstrated between single or dual platform results.[43]

It would be advisable to study peripheral B cell numbers in a larger sample of healthy Cuban individuals including different areas of the country to determine the possible relationship with regional and individual factors that may vary according to genetic ancestry, living conditions and lifestyles (e.g., nutrition, smoking) and air pollution. The composition of B cells in terms of memory cells and plasmablast proportions in Cuban individuals with high and low peripheral B cell levels should also be determined.

\section{CONCLUSIONS}

Absolute and percentage concentrations of lymphocyte subpopulations found in the Cuban sample were different from those obtained in other countries. Absolute and percentage values of the CD3+/CD4+ T phenotype are higher in women. Absolute values of total lymphocytes and of CD3+/CD8+ T lymphocytes are higher in younger participants. In percentage values CD3+/CD4+ T lymphocytes have lower values in older subjects. These differences justify adjusting clinical studies to different values by age and sex. The study supports improved diagnosis in Cuba, since it provides a new, albeit preliminary, set of reference values. -1 -

\section{REFERENCES}

1. McCoy JP Jr, Keren DF. Current practices in clinical flow cytometry. A practice survey by the American Society of Clinical Pathologists. Am J Clin Pathol. 1999 Feb;111(2):161-8.

2. Thompson MA, Aberg JA, Cahn P, Montaner JS, Rizzardini G, Telenti A, et al. International Aids Society-USA. Antiretroviral treatment of adult HIV infection: 2010 recommendations of the international AIDS society-USA panel. JAMA. 2010 Jul 21;304(3):321-33.

3. Lee SE, Yahng SA, Cho BS, Eom KS, Kim YJ, $\mathrm{Kim} \mathrm{HJ}$, et al. Lymphocyte subset analysis for the assessment of treatment-related complications after autologous stem cell transplantation in multiple myeloma. Cytotherapy. 2012 Apr;14(4):505-12.

4. Jentsch-Ullrich K, Koenigsmann M, Mohren M, Franke A. Lymphocyte subsets reference ranges in an age- and gender-balanced population of 100 healthy adults amonocentric German study. Clin Immunol. 2005 Aug;116(2):192-7.

5. Melzer S, Zachariae S, Bocsi J, Engel C, Löffler M, Tarnok A. Reference intervals for leukocyte subsets in adults: results from a population-based study using 10-color flow cytometry. Cytometry B Clin Cytom. 2015 JulAug:88(4):270-81.

6. Thakar MR, Abraham PR, Arora S, Balakrishnan $P$, Bandyopadhyay $B$, Joshi AA, et al. Establishment of reference CD4+ T cell values for adult Indian population. AIDS Res Ther. 2011 Oct 3;8:35.

7. World Medical Association. Declaration of Helsinki: ethical principles for medical research involving human subjects. JAMA [Internet]. 2013 Nov 27 [cited 2018 Jun 13];310(20):2191-4. Available from: https://jamanetwork.com/journals/ jama/fullarticle/10.1001/jama.2013.281053

8. Torres AJ, Angelo AL, Silva MO, Bastos MC, Souza DF, Inocencio LA, et al. Establishing the reference range for $T$ lymphocytes subpopulations in adults and children from Brazil. Rev Inst Med Trop Sao Paulo. 2013 Sep-Oct:55(5):323-8.

9. Cóndor JM, Álvarez M, Cano L, Matos E, Leiva C, Paredes JA. Intervalos de referencia de subpoblaciones linfocitarias de sangre periférica en adultos sanos de Lima, Perú. Rev Peru Med Exp Salud Publica. 2013 Apr;30(2):235-40. Spanish.

10. Saathoff E, Schneider P, Kleinfeldt V, Geis S, Haule D, Maboko L, et al. Laboratory reference values for healthy adults from southern Tanzania. Trop Med Int Health. 2008 May;13(5):612-25.

11. Choi J, Lee SJ, Lee YA, Maeng HG, Lee JK, Kang YW. Reference values for peripheral blood lymphocyte subsets in a healthy Korean population. Immune Netw. 2014 Dec;14(6):289-95.

12. Amatya R, Vajpayee M, Kaushik S, Kanswal S, Pandey RM, Seth P. Lymphocyte immunophenotype reference ranges in healthy Indian adults: Implications for management of HIV/Aids in India. Clin Immunol. 2004 Sep;112(3):290-5.

13. Torres AJ, Angelo AL, Netto EM, Sampaio GP, Souza DF, Inocêncio LA, et al. Reference range for $\mathrm{T}$ lymphocytes populations in blood donors from two different regions in Brazil. Braz $\mathrm{J}$ Infect Dis. 2009 Jun;13(3):221-5

14. Zhang K, Wang F, Zhang M, Cao X, Yang S, Jia $S$, et al. Reference ranges of lymphocyte subsets balanced for age and gender from a population of 
healthy adults in Chongqing District of China. Cytometry B Clin Cytom. 2016 Nov;90(6):538-42.

15. Mandala WL, Ananworanich J, Apornpong T, Kerr SJ, MacLennan JM, Hanson C, et al. Control Lymphocyte Subsets: Can one country's values serve for another's? J Allergy Clin Immunol. 2014 Sep;134(3):759-61.

16. Duramad P, Tager IB, Holland NT. Cytokines and other immunological biomarkers in children's environmental health studies. Toxicol Lett. $2007 \mathrm{Jul}$ $30 ; 172(1-2): 48-59$.

17. García-Dabrio MC, Pujol-Moix N, Martínez-Pérez A, Fontcuberta J, Souto JC, Soria JM, et al. Influence of age, gender and lifestyle in lymphocyte subsets: report from the Spanish Gait-2 Study. Acta Haematol. 2012;127(4):244-9.

18. Valiathan R, Deeb K, Diamante M, Ashman M, Sachdeva N, Asthana D. Reference ranges of lymphocyte subsets in healthy adults and adolescents with special mention of $\mathrm{T}$ cell maturation subsets in adults of South Florida. Immunobiology. 2014 Jul;219(7):487-96.

19. Anglaret $X$, Diagbouga S, Mortier E, Meda N, Verge-Valette V, Sylla-Koko F, et al. CD4+ T-lymphocyte counts in HIV infection: are European standards applicable to African patients? J Acquir Immune Defic Syndr Hum Retrovirol. 1997 Apr 1;14(4):361-70.

20. World Health Organization [Internet]. Geneva: World Health Organization; c2019. Fact sheets. Detail. Dengue and Severe Dengue; 2014 [cited 2014 Jul]. Available from: http://www.who.int/me diacentre/factsheets/fs117/en/

21. Thai KT, Wismeijer JA, Zumpolle $C$, de Jong MD, Kersten MJ, de Vries PJ. High incidence of peripheral blood plasmacytosis in patients with dengue virus infection. Clin Microbiol Infect. 2011 Dec;17(12):1823-8.

22. Correa AR, Berbel AC, Papa MP, Morais AT, Peçanha LM, Arruda LB. Dengue virus directly stimulates polyclonal B cell activation. PLoS ONE. 2015 Dec 10;10(12):e0143391.

23. Shahal-Zimra Y, Rotem Z, Chezar J, Shochat T, Ross L, Pickholtz I, et al. Lymphocyte subset reference ranges in healthy Israeli adults. Isr Med Assoc J. 2016 Dec;18(12):739-43.

24. Qin L, Jing X, Qiu Z, Cao W, Jiao Y, Routy JP, et al. Aging of immune system: Immune signature from peripheral blood lymphocyte subsets in 1068 healthy adults. Aging (Albany NY). 2016 May;8(5):848-59.

25. Lin $\mathrm{Y}$, Damjanovic A, Metter EJ, Nguyen H, Truong T, Najarro K, et al. Age-associated telomere attrition of lymphocytes in vivo is co-ordinated with changes in telomerase activity, composition of lymphocyte subsets and health conditions. Clin Sci (Lond). 2015 Mar;128(6):367-77.

26. Pang WW, Price EA, Sahoo D, Beerman I, Maloney WJ, Rossi DJ, et al. Human bone marrow hematopoietic stem cells are increased in frequency and myeloid-biased with age. Proc Natl Acad Sci U S A. 2011 Dec 13;108(50):20012-7.

27. Palmer DB. The effect of age on thymic function. Front Immunol. 2013 Oct 7;4:316.

28. Stervbo U, Bozzetti C, Baron U, Jürchott K, Meier $\mathrm{S}$, Mäalzer JN, et al. Effects of aging on human leukocytes (part II): immunophenotyping of adaptive immune B and T cell subsets. Age (Dordr). 2015 Oct:37(5):93.

29. Lin Y, Kim J, Metter EJ, Nguyen H, Truong T, Lustig A, et al. Changes in blood lymphocyte numbers with age in vivo and their association with the levels of cytokines/cytokine receptors. Immun Ageing. 2016 Aug 18;13:24

30. Boyman O, Purton JF, Surh CD, Sprent J. Cytokines and $T$ cell homeostasis. Curr Opin Immunol. 2007 Jun;19(3):320-6.

31. Wikby A, Ferguson F, Forsey R, Thompson J, Strindhall J, Löfgren S, et al. An immune risk phenotype, cognitive impairment, and survival in very late life: impact of allostatic load in Swedish octogenarian and nonagenarian humans. J Gerontol A Biol Sci Med Sci. 2005 May;60(5):556-65

32. Pawelec G, Ouyang Q, Colonna-Romano G, Candore $G$, Lio D, Caruso $C$. Is human immunosenescence clinically relevant? Looking for 'immunological risk phenotypes'. Trends Immunol. 2002 Jul;23(7):330-2.

33. Wikby A, Johansson B, Olsson J, Löfgren S, Nilsson BO, Ferguson F. Expansions of peripheral blood CD8 T-lymphocyte subpopulations and an association with cytomegalovirus seropositivity in the elderly: the Swedish NONA immune study. Exp Gerontol. 2002 Jan-Mar;37(2-3):445-53.

34. Apoil PA, Puissant-Lubrano B, Congy-Jolivet N, Peres M, Tkaczuk J, Roubinet F, et al. Influence of age, sex and HCMV-serostatus on blood lymphocyte subpopulations in healthy adults. Cell Immunol. 2017 Apr;314:42-53.

35. Villegas-Valverde CA, Kokuina E, Breff-Fonseca MC. Estimating normal values of rare T-lymphocyte populations in peripheral blood of healthy $\mathrm{Cu}$ ban adults. MEDICC Rev. 2018 Oct;20(4):20-6.

36. McCombe PA, Greer JM, Mackay IR. Sexual dimorphism in autoimmune disease. Curr Mol Med. 2009 Dec;9(9):1058-79.

37. Qi Q, Liu Y, Cheng Y, Glanville J, Zhang D, Lee JY, et al. Diversity and clonal selection in the human T-cell repertoire. Proc Natl Acad Sci USA. 2014 Sep 9;111(36):13139-44.

38. Oertelt-Prigione $S$. The influence of sex and gender on the immune response. Autoimmun Rev. 2012 May;11(6-7):A479-85.

39. Klein SL, Flanagan KL. Sex differences in immune responses. Nat Rev Immunol. 2016 Oct;16(10):626-38

40. Kissick HT, Sanda MG, Dunn LK, Pellegrini KL, On ST, Noel JK, et al. Androgens alter T-cell im- munity by inhibiting T-helper 1 differentiation. Proc Natl Acad Sci USA. 2014 Jul 8;111(27):9887-92.

41. Edwards $M$, Dai $R$, Ahmed SA Our environment shapes us: the importance of environment and sex differences in regulation of autoantibody production. Front Immunol. 2018 Mar 8;9:478.

42. Yan J, Greer JM, Hull R, O'Sullivan JD, Henderson RD, Read SJ, et al. The effect of ageing on human lymphocyte subsets: comparison of males and females. Immun Ageing 2010;7:4.

43. Hultin LE, Chow M, Jamieson BD, O'Gorman $M R$, Menéndez FA, Borowski L, et al. Comparison of interlaboratory variation in absolute T-cell counts by single-platform and optimized dualplatform methods. Cytometry B Clin Cytom. 2010 May;78(3):194-200.

\section{ACKNOWLEDGMENTS}

With appreciation to the technical personnel of the Clinical Laboratory, Hermanos Ameijeiras Clinical-Surgical Teaching Hospital (HCQHA), and all the volunteers who participated in this study.

\section{THE AUTHORS}

Elena Kokuina (Corresponding author: inmunologia@hha.sld.cu), physician specializing in immunology, with a doctorate in medical sciences. Clinical Laboratory, HCQHA, Havana, Cuba.

Martha C. Breff-Fonseca, physician and clinical laboratory specialist, Clinical Laboratory, HCQHA, Havana, Cuba.

Carlos A. Villegas-Valverde, physician with dual specialties in family medicine and immunology, and master's degrees in infectious diseases and medical education. Associate researcher, Immunology Laboratory of the National Institute of Oncology and Radiobiology, Havana, Cuba.

Isabel Mora-Díaz, physician specializing in biostatistics, Research Department, HCQHA, Havana, Cuba.

Submitted: January 31, 2019

Approved for publication: June 30, 2019

Disclosures: None 